Jurnal Dinamika Sosial Ekonomi Vol.21 No.2, Desember 2020 : 163-177

ISSN 1411-593X (print); ISSN 2721-3137 (online)

\title{
PERUBAHAN INTERAKSI SOSIAL MASYARAKAT KAMPUNG AGRO DI PILAHAN KOTA YOGYAKARTA
}

\author{
SOCIAL INTERACTION CHANGES OF THE COMMUNITY IN PILAHAN \\ AGRO VILLAGE YOGYAKARTA
}

\author{
Nicka Adelia Audianawati, Teguh Kismantoroadji, Daru Retnowati \\ Program Studi Agribisnis Fakultas Pertanian \\ Universitas Pembangunan Nasional Veteran Yogyakarta \\ Jl. SWK 104, Condongcatur, Kecamatan Depok, \\ Kabupaten Sleman, Yogyakarta, Indonesia \\ *email koresponden : nickadelia@gmail.com
}

Diterima tanggal : 17 September 2020 ; Disetujui tanggal : 21 September 2020

\begin{abstract}
This research aims to examine social interaction changes of the community in Agro Village. This research used qualitative approach method. The Agro Village was chosen because the capability to manage an agricultural village to support food security among the surrounding urban areas. The Purposive Sampling technique was used to determine the informants. The informants consist of 20102015 Rejowinangun Headman, 2015-2020 Rejowinangun Headman, Secretary of Rejowinangun Tourism Cluster, Group of Practical Field Project (PPL), and the Chairman of Agro Village whose directly involved on the program implementaion. The data sources used for this research were primary and secondary data. The data collected used observation, interview, and documentation technique. Data analysis technique to examine the goal for this research consist of data collection, data reduction, data presentation, and conclusion withdrawal. The obtained results conclude that the process of social interaction changes can be seen by the community social contact which includes primary social contact, direct secondary social contact, and indirect social contact. In addition, the community social contact includes interaction tools, community mindset, and social organization. Changes that occured in Agro Village were associative assimilation changes. This noticeable changes can be seen by the community unification.
\end{abstract}

Keywords: Agro Village Yogayakarta, Changes, Community, Social Interaction.

\begin{abstract}
ABSTRAK
Penelitian ini bertujuan untuk mengkaji perubahan interaksi sosial masyarakat di Kampung Agro. Penelitian ini menggunakan pendekatan kualitatif. Lokasi penelitian dipilih karena Kampung Agro merupakan wilayah perkotaan yang mampu mengelola program ketahanan pangan yaitu Kampung Agro. Teknik penentuan informan yaitu purposive sampling. Informan dalam penelitian ini
\end{abstract}


adalah Lurah Rejowinangun tahun 2010-2015, Lurah Rejowinangun tahun 20152020, Sekretaris Kampung Wisata Cluster Rejowinangun, PPL dan ketua Kampung Agro karena yaitu orang yang terlibat langsung dalam pelaksanaan program. Sumber Data yang digunakan adalah data primer dan data sekunder. Teknik pengumpulan data yaitu menggunakan observasi, wawancara dan dokumentasi. Teknik analisis data untuk mengkaji tujuan penelitian yaitu dengan mengumpulkan data, mereduksi data, penyajian data, dan penarikan kesimpulan. Hasil penelitian menunjukkan bahwa proses perubahan interaksi sosial masyarakat dapat dilihat dari kontak sosial yang meliputi kontak sosial primer, kontak sosial sekunder langsung dan kontak sosial sekunder tak langsung. Sedangkan komunikasi sosial yang meliputi alat untuk bertinteraksi, pola pikir masyarakat, dan organisasi sosial. Bentuk perubahan interaksi sosial yang terjadi di Kampung Agro merupakan perubahan asimilasi yang bersifat asosiatif. Hal ini terlihat dari perubahan interaksi sosial yang mengarah pada penyatuan masyarakat Kampung Agro

Kata kunci: Perubahan, Interaksi Sosial, Masyarakat, Kampung Agro Yogyakarta

\section{PENDAHULUAN}

Kampung Pilahan di Jalan Nyi Adisari, Gg. Dahlia I pilahan KG I No.722, Kelurahan Rejowinangun, Kecamatan Kotagede, Kota Yogyakarta dengan kondisi lingkungan minim akan tanaman. Mata pencaharian Masyarakat Kampung Pilahan bermacam-macam, disamping itu pula masih terdapat banyak masyarakat yang menganggur. Dalam berinteraksi antar warga di Kampung Pilahan jarang dilakukan terutama antar rumah. Masyarakat Pilahan bertemu pada saat diadakannya pertemuan rutin. Kehidupan yang ada di wilayah masih individualis.

Pada tahun 2011 Kampung Pilahan merintis program yang dapat mengupayakan dan swadaya secara menyeluruh untuk menjadikan Pilahan sebagai "Kampung Hijau”. Program Kampung Hijau berisikan sosialisasi gerakan penanaman setiap rumah untuk menanam 5 tanaman buah dan sayuran dengan menggunakan media polybag, pot, atau lahan yang ditanam disekitar lingkungan rumah baik ditembok. pagar, atap maupun diatas selokan. Tahun 2012 Program Kampung Hijau berkembang menjadi menjadi Kampung Agro. Kampung Agro terbagi menjadi 3 RW, yaitu RW 11 sebagai kampung anggrek, RW 12 sebagai kampung agro edukasi khusus tanaman sayur dan buah, serta RW 13 sebagai kampung flori khusus tanaman hias. 
Audianawati et.al. Perubahan Interaksi Sosial Masyarakat Kampung Agro di.......

Kampung Agro memiliki berbagai kegiatan, diantaranya Kegiatan 1 rumah menanam 5 tanaman dengan basis memanfaatkan lahan, Pelatihan bertanam dan pengemasan produk, Membuat Spot selfie untuk menarik wisatawan, Mempromosikan Kampung Agro melalui media massa, menciptakan Kampung Agro Edukasi, Membuat kripik daun, mengembangkan teknik budidaya tanaman, Studi banding ke Bogor, serta Mengikuti Gelar Potensi. Setelah berbagai dari Program Kampung Agro berlanjut, kondisi Pilahan menjadi asri, dikenal berbagai kalangan, dan meraih berbagai prestasi. Prestasi yang diraih salah satunya ialah mendapatkan Rekor MURI karena Kampung Agro telah membuat 272 jenis kripik daun. Maka dari hal tersebut, pada tahun 2017 hingga tahun 2018 Kampung Agro semakin sering dikunjungi oleh para wisatawan.

Dengan adanya Program Kampung Agro tersebut tentu menimbulkan beberapa perubahan-perubahan di dalam Masyarakat Pilahan. Perubahan tersebut terjadi pada interaksi sosial masyarakat karena adanya interaksi antara wisatawan dengan masyarakat yang menimbulkan interaksi baru di Kampung Agro. Menurut Soekanto (2012) Interaksi sosial dapat diartikan sebagai hubungan sosial yang dinamis merupakan bentuk umum dari proses sosial. Interaksi sosial dapat didefinisikan sebagai hubungan timbal balik antara individu dengan individu, kelompok dengan kelompok, serta individu dengan kelompok. Teori Mead dalam Soekanto (2012) mengemukakan bahwa interaksi sosial tidak mungkin terjadi tanpa adanya dua syarat, yaitu:

1. Kontak Sosial, kontak sosial terbagi menjadi 2 yaitu kontak sosial (primer) merupakan hubungan setiap pihak dalam berinteraksi baik dengan berbicara, tatap muka ataupun dengan bersalaman. Kontak sosial (sekunder) merupakan hubungan dengan pihak lain tanpa bersentuhan baik secara langsung yaitu melalui telepon, radio, surat maupun kontak sosial sekunder tak langsung yaitu dengan perantara pihak ketiga.

2. Komunikasi Sosial, merupakan pengiriman dan penerimaan pesan atau berita antara dua orang atau lebih sehingga pesan yang dimaksud dapat dipahami. Hal terpenting dalam komunikasi sosial adalah kegiatan saling menafsirkan 
perilaku (pembicaraan, gerakan-gerakan fisik, atau sikap) dan perasaanperasaan yang disampaikan.

Menurut Soekanto (2012), Interaksi sosial dibedakan menjadi dua bentuk, yaitu asosiatif dan disosiatif:

\section{Asosiatif}

Interaksi sosial yang bersifat asosiatif akan mengarah pada bentuk penyatuan. Asosiatif terdiri dari Kerjasama, akomodasi, asimilasi, akulturasi, dll

\section{Disosiatif}

Interaksi sosial yang bersifat disosiatif akan mengarah pada bentuk pemisahan.

Soekanto (2012) juga mengemukakan bahwa Perubahan dapat diketahui dengan membandingkan keadaan masyarakat dalam satu waktu dengan keadaan yang lampau. Oleh karena itu perlu dikaji mengenai perubahan interaksi masyarakat yang terjadi di Pilahan dengan adanya Kampung Agro melalui kontak sosial dan komunikasi sosial.

\section{METODE PENELITIAN}

Lokasi penelitian berada di Kampung Pilahan, Kelurahan Rejowinangun, Kecamatan Kotagede. Yogyakarta karena wilayah tersebut merupakan wilayah perkotaan yang mampu menjaga ketahan pangan masyarakat melalui Program Kampung Agro. Waktu penelitian dilakukan dari bulan Desember 2019 sampai dengan Maret 2020. Jenis penelitian yang digunakan adalah penelitian kualitatif dengan pendekatan studi kasus. Fokus penelitian yang diamati ialah Perubahan interaksi sosial masyarakat di Kampung Agro. Teknik penentuan informan dilakukan dengan cara purposive sampling yaitu teknik pengambilan sampel sumber data dengan pertimbangan tertentu, misalnya orang tersebut dianggap paling tahu tentang apa yang kita harapkan (Sugiyono, 2011). Subjek penelitian dalam penelitian ini adalah sumber informasi atau orang yang paling paham mengenai data yang dibutuhkan yaitu Ibu Lurah Rejowinangun tahun 2010-2015, Ibu Lurah Rejowinangun tahun 2015-2020, Sekretaris Kampung Wisata Cluster Rejowinangun., ketua Kampung Agro dan Petugas Penyuluh Lapangan (PPL). 
Audianawati et.al. Perubahan Interaksi Sosial Masyarakat Kampung Agro di.......

Teknik pengumpulan data yang digunakan dalam penelitian kualitatif adalah observasi, wawancara, dan dokumentasi (Sugiyono, 2011). Dalam penelitian ini untuk menguji keabsahan data menggunakan triangulasi teknik untuk menguji kredibilitas data dilakukan dengan cara mengecek data kepada sumber yang sama dengan teknik yang berbeda (Sugiyono, 2011). Miles dan Huberman (1984) dalam Sugiyono (2011) mengemukakan bahwa akivitas dalam analisis data kualitatif dilakukan secara interaktif dan berlangsung secara terus menerus sampai tuntas, sehingga datanya sudah jenuh. Analisis data yang dilakukan berupa data reduction, data display, dan conclusion drawing/verification

\section{HASIL DAN PEMBAHASAN}

Kampung Hijau berkembang menjadi Kampung Agro. Masyarakat Pilahan mengalami beberapa perubahan karena adanya Kampung Agro. Perubahan tersebut terjadi pada interaksi sosial Masyarakat Pilahan melalui kontak sosial dan komunikasi sosial Masyarakat Pilahan. Perubahan tersebut dapat diketahui dengan membandingkan keadaan masyarakat sebelum adanya Kampung Agro dengan setelah adanya Kampung Agro. Hal tersebut sesuai dengan pernyataan Soekanto (2012) bahwa interaksi sosial tidak mungkin terjadi tanpa adanya dua syarat, yaitu kontak sosial dan komunikasi sosial. Perubahan dapat diketahui dengan membandingkan keadaan masyarakat dalam satu waktu dengan keadaan yang lampau.

\section{Kontak Sosial}

Kontak sosial merupakan sekumpulan proses aksi dan reaksi sosial dalam kehidupan masyarakat. Kontak sosial dapat terjadi secara langsung dan tidak langsung. Menurut Soekanto (2012) Kontak sosial terjadi melalui 3 macam, yaitu kontak sosial primer, kontak sosial sekunder langsung dan tak langsung. Kontak sosial primer terjadi apabila terdapat hubungan langsung bertemu dan berhadapan muka, kontak sosial sekunder langsung dan tak langsung terjadi apabila terdapat hubungan melalui suatu perantara yaitu menggunakan media penunjang interaksi berupa teknologi atau dengan pihak ketiga. Kontak sosial 
langsung terjadi apabila yang mengadakan hubungan langsung bertemu dan berhadapan muka, sedangkan kontak sosial tidak langsung terjadi apabila hubungan sosial terjadi melalui suatu perantara yaitu bisa menggunakan media penunjang interaksi berupa teknologi. Hal tersebut sesuai dengan pernyataan Mulyaningsih (2014) bahwa kontak sosial tidak sekedar bergantung pada tindakan, akan tetapi juga tanggapan atau reaksi terhadap tindakan tersebut. Hasil penelitian Sihabudin (2010) juga menyatakan bahwa kontak sosial dapat dikatakan sebagai kegiatan komunikasi interpersonal, hubungan beberapa orang yang terjadi diantara mereka dapat dikatakan sebagai komunikasi kelompok, kontak dengan media apakah surat kabar, televisi dan lain-lain dapat dikatakan sebagai proses komunikasi massa. Artinya kontak bisa saja terjadi baik dengan manusia maupun benda.

Dengan demikian, kontak sosial di Kampung Agro dapat terjadi melalui interaksi antar masyarakat dan media penunjang interaksi yang ada di dalam masyarakat.

\section{a. Kontak sosial primer}

Perubahan kontak sosial dapat dilihat melalui Interaksi antar masyarakat sebelum dan setelah adanya Kampung Agro. Hal tersebut sesuai dengan pernyataan Mulyadi (2015) bahwa perubahan dapat diketahui bila kita melakukan suatu perbandingan dengan menelaah suatu masyarakat pada masa tertentu dengan keadaan masyarakat pada waktu yang lampau.

Interaksi antar Masyarakat Pilahan sebelum adanya Program Kampung Agro ialah Interaksi masyarakat Kampung Pilahan masih individualis. Masyarakat antar RW kurang saling mengenal satu sama lain. Namun, ada pula antar warga yang hanya sebatas saling mengenal. Warga Pilahan hanya bertemu pada saat adanya pertemuan rutin yang diadakan RW maupun RT sehingga komunikasi tidak terjalin secara maksimal dan keseluruhan. 


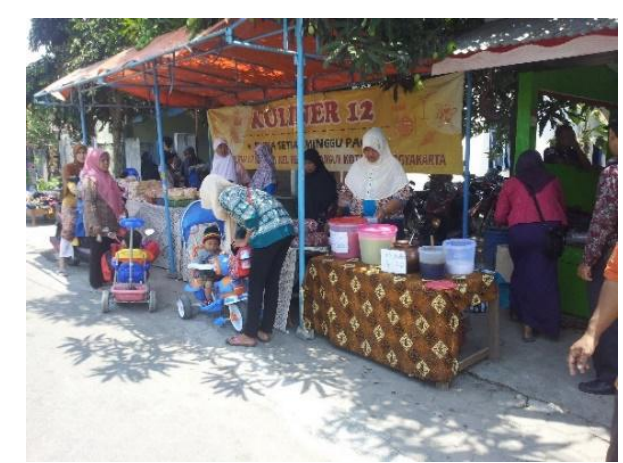

Gambar 1. Interaksi Antar Warga

Sumber: Dokumentasi Kampung Agro (2015)

Berdasarkan Gambar 1, serta hasil pengamatan yang dilakukan oleh peneliti dapat dilihat bahwa, budaya saling tegur dan saling sapa saat bertemu dijalan masih dilakukan oleh masyarakat Kampung Agro. Interaksi antar masyarakat yang digunakan Masyarakat Pilahan sesudah adanya Kampung Agro yaitu Masyarakat Kampung Pilahan semakin sering bertemu dan berinteraksi tidak hanya di kegiatan organisasi, acara besar desa dan acara hajatan saja. Masyarakat Kampung Pilahan semakin sering bertemu dan berinteraksi tidak hanya di kegiatan organisasi, acara besar Pilahan dan acara hajatan. Masyarakat saling bertemu dan berinteraksi sehingga kendala yang dialami dapat teratasi. Misal ada masyarakat yang kekurangan bibit atau mengalami kendala saat budidaya masyarakat lain membantu. Masyarakat Pilahan menjadi lebih guyub

b. Kontak sosial sekunder langsung dan tak langsung (Sebelum dan setelah adanya Program Kampung Agro)

Perubahan kontak sosial dapat dilihat melalui Interaksi antar masyarakat sebelum dan setelah adanya Kampung Agro. Hal tersebut sesuai dengan pernyataan Mulyadi (2015) bahwa perubahan dapat diketahui bila kita melakukan suatu perbandingan dengan menelaah suatu masyarakat pada masa tertentu dengan keadaan masyarakat pada waktu yang lampau

Media penunjang interaksi langsung yang digunakan Masyarakat Pilahan sebelum adanya Masyarakat Pilahan menggunakan toa dan papan pengumuman yang terdapat berbagai masjid untuk berinteraksi. Selain itu, 
komunikasi yang digunakan antar warga menggunakan Handphone yang berupa $S M S$ atau telepon. Untuk undangan pertemuan atau kegiatan lain Masyarakat Pilahan menggunakan surat. Sedangkan media penunjang interaksi tak langsung dilakukan dengan cara Ibu Lurah menghimbau masyarakat untuk bertanam dan orang yang tidak bertemu dengan Ibu Lurah mengingatkan masyarakat lain untuk mengikuti kegiatan bertanam. Saat masyarakat yang kesulitan mencari bahan dalam bertanam dapat meminta bantuan Pak Darma sebagai ketua Kampung Agro.

Media penunjang interaksi langsung yang digunakan Masyarakat Pilahan sesudah adanya Masyarakat Pilahan menggunakan aplikasi WhatsApp untuk berkomunikasi ke seluruh Masyarakat Pilahan melalui Fitur Group Kampung Agro. Media sosial seperti Facebook, Instagram, dan Web digunakan Masyarakat Pilahan untuk mempromosikan dan memperkenalkan Kampung Agro, sedangkan Gelar Potensi Pertanian diikuti oleh Masyarakat Pilahan untuk memperlihatkan hasil budidaya tanaman Kampung Agro. Kedua cara ini dilakukan untuk memperkenalkan, mempromosikan, dan memperlihatkan Kampung Agro ke masyarakat yang lebih luas

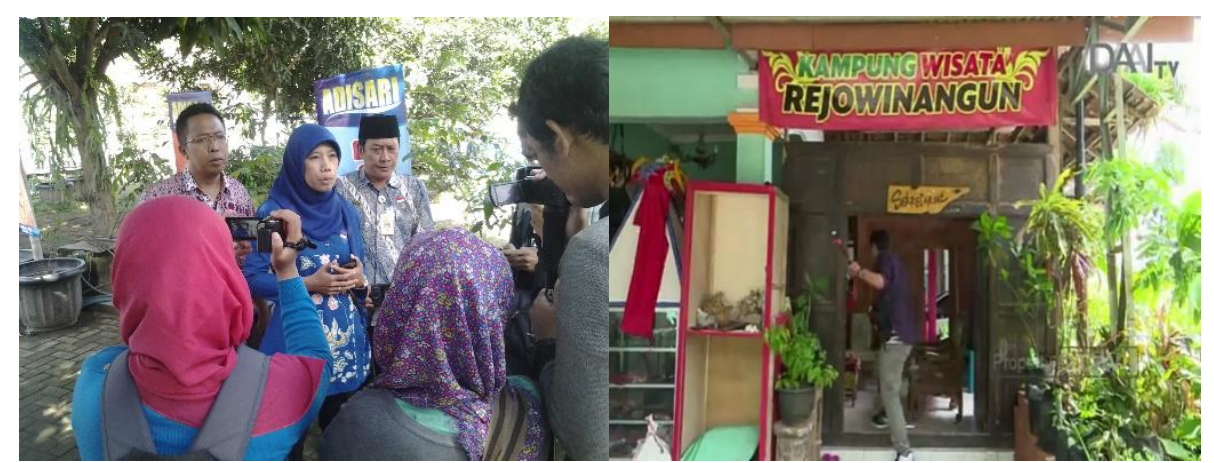

Gambar 2. Kunjungan Stasiun TV

Sumber: Dokumentasi Kampung Agro (2017)

Berdasarkan Gambar 2, Kampung Agro memanfaatkan berbagai berbagai macam media massa dan media sosial untuk mempromosikan potensi yang ada. Media sosial yang telah digunakan Kampung Agro ialah Web, Instagram, dan Facebook. Sedangkan media massa yang telah 
Audianawati et.al. Perubahan Interaksi Sosial Masyarakat Kampung Agro di.......

membantu Kampung Agro untuk mempromosikan potensi yang ada ialah Adisari TV dan DAAI TV.

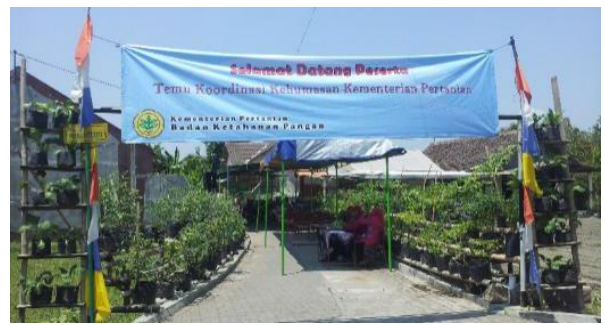

Gambar 3 Gelar Potensi

Sumber: Dokumentasi Kampung Agro (2018)

Selain dengan media massa maupun media sosial. Berdasarkan Gambar 3, Kampung Agro mengikuti berbagai berbagai kegiatan Gelar Potensi Pertanian untuk memperkenalkan dan mempromosikan hasil dari budidaya tanaman yang ada di Kampung Agro kepada masyarakat yang lebih luas. Sedangkan media penunjang tak langsung dilakukan dengan cara Ibu Lurah menghimbau masyarakat untuk bertanam dan orang yang tidak bertemu dengan Ibu Lurah meminta bantuan dinas untuk memberikan berbagai pelatihan untuk Kampung Agro. Saat masyarakat tidak dapat hadir dalam pertemuan atau pelatihan yang diadakan di Kampung Agro, masyarakat menitipkan izin ke masyarakat lain untuk disampaikan ke ketua program

\section{Komunikasi Sosial}

Komunikasi sosial merupakan suatu proses interaksi antara individu dengan individu, individu dengan kelompok atau kelompok dengan kelompok yang saling memberikan pengaruh satu sama lainnya, pengaruh tersebut dapat mengembangkan pengetahuan individu atau kelompok tersebut. Hal tersebut sesuai dengan pernyataan Mudjiono (2012) bahwa komunikasi sosial terjadi antar individu dalam kehidupannya di masyarakat yang memiliki konteks dalam segala dimensi kehidupan manusia. Seluruh dimensi kehidupan manusia dipenuhi dengan komunikasi. Komunikasi sosial mengisyaratkan bahwa berkomunikasi itu penting untuk membangun konsep diri, aktualisasi diri, 
untuk kepentingan hidup, untuk memperoleh kebahagiaan, terhindar dari tekanan dan ketegangan.

Dengan demikian, komunikasi sosial dapat terjadi melalui alat untuk berinteraksi antar masyarakat, pola pikir masyarakat, dan organisasi sosial yang ada di dalam masyarakat karena dalam organisasi sosial di Kampung Agro, individu dapat mempengaruhi pola pikir kelompok atau bahkan sebaliknya menggunakan alat untuk berinteraksi.

a. Alat untuk berinteraksi antar masyarakat (Sebelum dan setelah adanya Kampung Agro)

Perubahan komunikasi sosial dapat dilihat melalui alat untuk berinteraksi antar masyarakat berupa bahasa sebelum dan setelah adanya Kampung Agro. Hal tersebut sesuai dengan pernyataan Mulyadi (2015) bahwa perubahan dapat diketahui bila kita melakukan suatu perbandingan dengan menelaah suatu masyarakat pada masa tertentu dengan keadaan masyarakat pada waktu yang lampau.

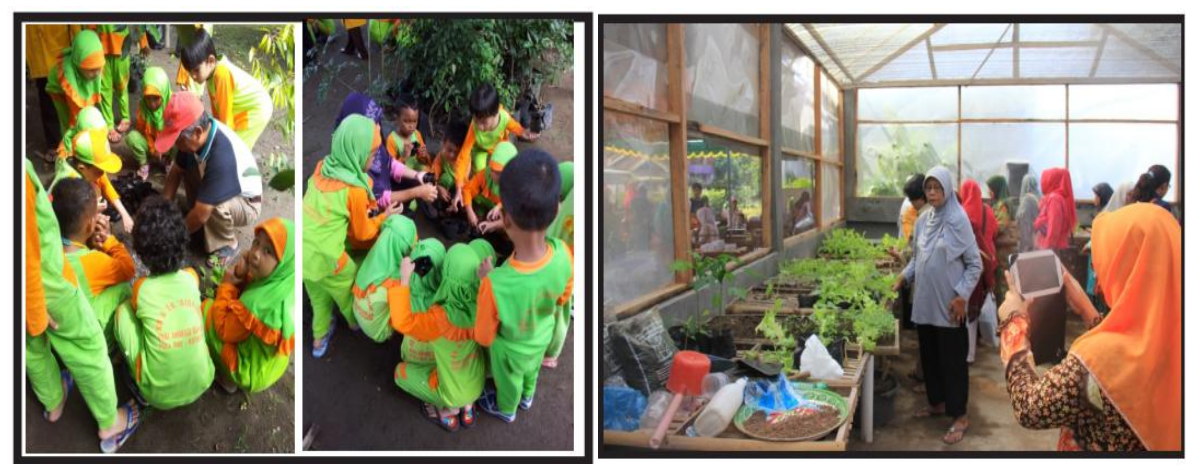

Gambar 4 Kunjungan Wisatawan Sumber: Dokumentasi Kampung Agro (2014)

Berdasarkan Gambar 4, Kampung Agro memiliki berbagai wisatawan yang berkunjung untuk belajar budidaya bertanam. Mulai dari anak-anak hingga dewasa datang berkunjung untuk belajar Alat untuk berinteraksi antar masyarakat Pilahan sebelum adanya Program Kampung Agro yaitu masyarakat menggunakan Bahasa Jawa dan Bahasa Indonesia. Alat untuk berinteraksi antar masyarakat setelah adanya Program 
Audianawati et.al. Perubahan Interaksi Sosial Masyarakat Kampung Agro di.......

Kampung Agro yaitu dalam berinteraksi masyarakat menggunakan Bahasa Jawa dan Bahasa Indonesia, menyesuaikan masyarakat serta wisatawan yang diajak untuk berinteraksi. Jika pada saat bertemu dengan masyarakat yang usianya jauh lebih tua menggunakan Bahasa Jawa halus. Kemudian, jika ada tamu asing yang berkunjung masyarakat menggunakan Guide yang berasal dari Masyarakat Pilahan yang dapat ber-Bahasa Inggris.

\section{b. Pola pikir masyarakat (Sebelum dan setelah adanya Program Kampung Agro)}

Perubahan komunikasi sosial dapat dilihat melalui pola pikir masyarakat sebelum dan setelah adanya Kampung Agro. Hal tersebut sesuai dengan pernyataan Mulyadi (2015) bahwa perubahan dapat diketahui bila kita melakukan suatu perbandingan dengan menelaah suatu masyarakat pada masa tertentu dengan keadaan masyarakat pada waktu yang lampau

Pola pikir Masyarakat Pilahan sebelum adanya Program Kampung Agro yaitu Ada yang setuju dengan adanya Kampung Agro dan ada yang tidak setuju. Menurut masyarakat Program Kampung Agro merepotkan dan menambah pekerjaan masyarakat. Karena masyarakat perkotaan adalah pekerja yang memiliki sifat individual dan mudah lelah. Partisipasi masyarakat masih cukup besar dalam organisasi sosial di Pilahan dan masyarakat selalu mengikuti kegiatan tersebut kecuali yang berhalangan hadir dengan alasan yang logis. Pada dasarnya masyarakat hanya berbicara tentang tanaman buah, tanaman penghijauan, tetapi belum mendapatkan manfaat dari bertanam. Pengetahuan masyarakat masih terbatas akan pentingnya menanam tanaman untuk kebutuhan harian, Wilayah Pilahan masih terlihat gersang karena minimnya tanaman. Budaya gotong royong yang ada dalam kehidupan bermasyarakat hampir hilang. 


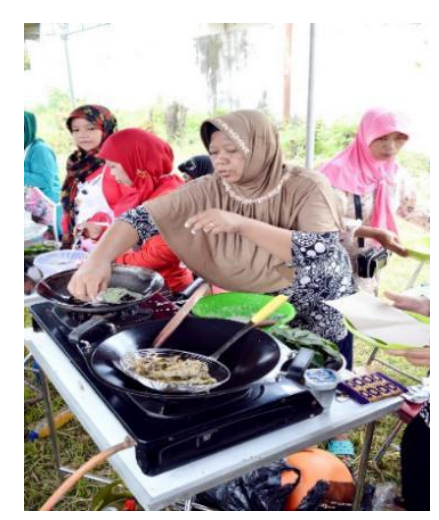

Gambar 5. Kegiatan Membuat Kripik di Kampung Agro Sumber: Dokumentasi Kampung Agro (2015)

Berdasarkan Gambar 5, masyakart berinteraksi dan berdiskusi untuk menjalankan kegiatan di Kampung Agro. Pola pikir Masyarakat Pilahan sesudah adanya Kampung Agro ialah pendekatan komunikasi aktif oleh Lurah dengan bukti serta komunikasi yang baik dan terus-menerus merubah mindset masyarakat. Hasil dari kegiatan dirasakan oleh Masyarakat Pilahan, seperti pengurangan belanja, dan bertambahnya lapangan pekerjaan melalui program instruktur dan UKM. Masyarakat Pilahan menjadi lebih aktif mengadakan pertemuan untuk mengembangkan, mengelola, dan mempromosikan Kampung Agro. Melalui budidaya bertanam pengurangan biaya belanja harian dirasakan oleh Masyarakat Pilahan. Dengan adanya Kampung Agro ini, gizi harian keluarga dapat terpenuhi dan dapat menikmati hasil budidaya tanaman sendiri. Kegiatan bertanam yang dilakukan oleh masyarakat menjadikan Pilahan lebih hijau dan sehat. Adanya Kampung Agro menumbuhkan kembali sikap gotongroyong dalam hidup bermasyarakat.

c. Organisasi sosial yang ada di dalam masyarakat (Sebelum dan setelah adanya Program Kampung Agro)

Perubahan komunikasi sosial dapat dilihat melalui organisasi sosial yang ada didalam masyarakat sebelum dan setelah adanya Kampung Agro. 
Audianawati et.al. Perubahan Interaksi Sosial Masyarakat Kampung Agro di.......

Hal tersebut sesuai dengan pernyataan Mulyadi (2015) bahwa perubahan dapat diketahui bila kita melakukan suatu perbandingan dengan menelaah suatu masyarakat pada masa tertentu dengan keadaan masyarakat pada waktu yang lampau.

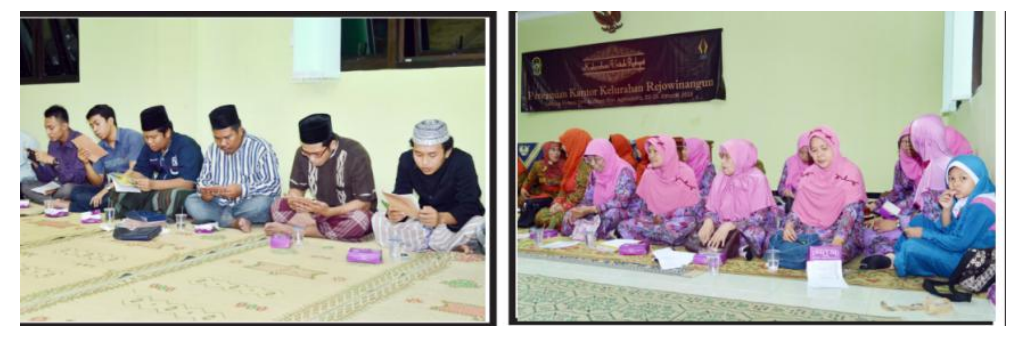

Gambar 6. Pengajian di Kampung Agro Sumber: Dokumentasi Kampung Agro (2020)

Berdasarkan Gambar 6, Organisasi sosial merupakan organisasi yang hadir di lingkungan Masyarakat Pilahan, dimana organisasi sosial tersebut didirikan oleh mereka yang memiliki jiwa sosial yang tinggi dan peduli terhadap kondisi masyarakat. Organisasi sosial memiliki suatu tujuan sosial, seperti untuk melayani kepentingan masyarakat, mengembangkan lingkungan masyarakat, dan lain sebagainya tanpa menghitung adanya untung maupun rugi. Organisasi sosial Masyarakat Pilahan sebelum adanya Kampung Agro yaitu Kelompok Tani Aisyah, Sinta Mina, RT, RW, PKK, pengajian, dasawisma, dan Bimasuta.

Organisasi sosial yang terjalin oleh Masyarakat Pilahan setelah adanya Program Kampung Agro adalah Organisasi sosial di Kampung Agro terdapat 37 organisasi sosial yang dibagi menjadi 7 bidang, diantaranya bidang sosial budaya, keamanan, lingkungan hidup, pembangunan, kepemudaan, dan ekonomi. Bidang ekonomi terdiri dari persewaan tenda dan kursi, bidang Keamanan yaitu Siskamling, Linmas, FKPM (Forum Kemitraan Polisi berbasis Masyarakat) dengan nama SEROJA (Semangat Rejowinangun Aman), bidang sosial diantaranya PKK, RT, RW, pengajian, dasawisma. dll. Bidang lingkungan hidup diantara Agro 37, Sinta Mina, KWT Aisyah, khusus anggrek ya anggrek 40, sesuai tanamannya. 
Soekanto (2012) mengemukakan bahwa proses perubahan interaksi sosial terbagi dalam dua bentuk yaitu perubahan interaksi asosiatif dan perubahan interaksi disosiatif. Proses perubahan interaksi asosiatif merupakan hubungan masyarakat dalam bentuk penyatuan, sedangkan perubahan disosiatif adalah interaksi sosial yang mengarah pada bentuk pemisahan. Perubahan interaksi sosial masyarakat melalui komunikasi sosial yang terjadi di Kampung Agro merupakan bentuk perubahan interaksi sosial yang terjadi di Kampung Agro merupakan suatu asimilasi. Proses asimilasi ditandai dengan adanya usaha mengurangi perbedaan yang terdapat diantara beberapa orang atau kelompok dalam masyarakat serta usaha menyamakan sikap, mental, dan tindakan demi tercapainya tujuan bersama sehingga bersifat asosiatif. Hal ini terlihat dari perubahan interaksi sosial yang mengarah pada penyatuan masyarakat Kampung Agro.

\section{KESIMPULAN DAN SARAN}

\section{Kesimpulan}

Proses perubahan interaksi sosial Masyarakat Pilahan terjadi melalui kontak sosial yang meliputi kontak sosial primer dan kontak sosial sekunder langsung serta tak langsung. Sedangkan komunikasi sosial yang meliputi alat untuk bertinteraksi, pola pikir masyarakat, dan organisasi sosial. Bentuk perubahan interaksi sosial masyarakat yang terjadi di Kampung Agro merupakan suatu asimilasi karena terjadi proses usaha mengurangi perbedaan yang terdapat pada beberapa orang atau kelompok dalam masyarakat serta usaha menyamakan sikap, mental, dan tindakan demi tercapainya tujuan bersama sehingga bersifat asosiatif. Hal ini terlihat dari perubahan interaksi sosial yang mengarah pada penyatuan masyarakat Kampung Agro.

\section{Saran}

Dalam proses perubahan interaksi sosial Masyarakat Pilahan di Kampung Agro sebaiknya Kelompok pemuda Bimasuta ikut terlibat dan membantu dalam kegiatan Gelar Potensi Pertanian serta ikut mengembangkan berbagai fasilitas 
Audianawati et.al. Perubahan Interaksi Sosial Masyarakat Kampung Agro di.......

wisata yang terdapat di Kampung Agro seperti mengganti atau menambahkan properti dalam Spot Selfie.

\section{DAFTAR PUSTAKA}

Mudjiono, Yoyon. (2012). Komunikasi Sosial. Jurnal Ilmu Komunikasi, 2(1), 99112.

Mulyadi, M. (2015). Perubahan Sosial Masyarakat Agraris Ke Masyarakat Industri Dalam Pembangunan Masyarakat Di Kecamatan Tamalate Kota Makassar. Jurnal Bina Praja, 7(4), 311-322.

Mulyaningsih, I.E. (2014). Pengaruh Interaksi Sosial Keluarga, Motivasi Belajar, dan Kemandirian Belajar Terhadap Prestasi Belajar. Jurnal Pendidikan dan Kebudayaan, 20(4), 441-451.

Sihabudin, Ahmad. (2010). Pengaruh Interaksi Sosial Komunitas Adat Budaya Luar Terhadap Persepsinya pada Kebutuhan Keluarga. Jurnal Penyuluhan, 6(1), 96-107.

Soekanto, S. (2012). Sosiologi : Suatu Pengantar. Jakarta: Yayasan Penerbit Universitas Indonesia.

Sugiyono. (2011). Metode Penelitian Kuantitatif, Kualitatif, dan $R \&$ D. Bandung: Alfabeta. 